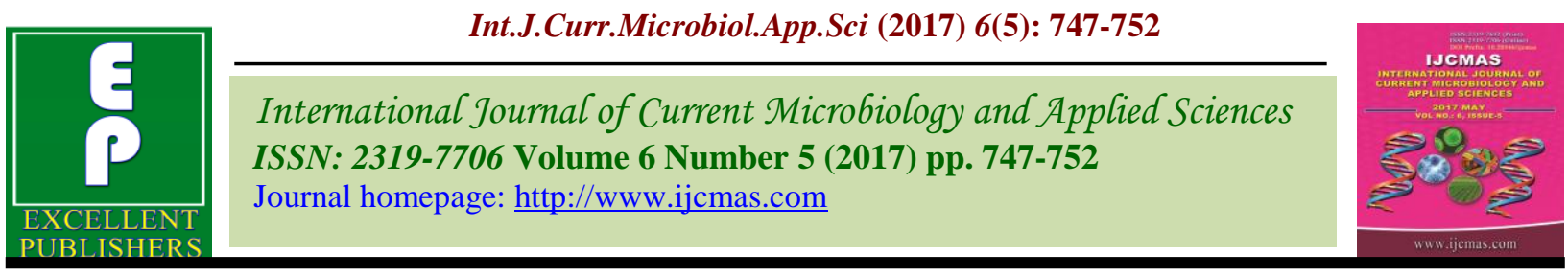

Original Research Article

https://doi.org/10.20546/ijcmas.2017.605.084

\title{
Evaluation of CD4 Cell Count and its Associating Factors - In HIV-TB Co-Infection
}

\author{
Jyotsna Chandwani*, Priyanka Soni, Geeta Parihar and Chandrakant Meena \\ Department of Microbiology, JLN Medical College and Hospital, Ajmer, India \\ *Corresponding author:
}

\section{A B S T R A C T}

\begin{tabular}{|c|c|}
\hline Keywords & $\begin{array}{l}\text { ing the leading cause of death among } \\
\text { IV-TB co-infection, leads to an increase in morbidity and mortality. So this }\end{array}$ \\
\hline $\begin{array}{l}\text { CD4 count, } \\
\text { extra-pulmonary } \\
\text { TB, pulmonary } \\
\text { TB, HIV. }\end{array}$ & $\begin{array}{l}\text { study was done to evaluate the CD4 cell count and its associating factors in HIV-TB co } \\
\text { infection to estimate their immune status. This was a retrospective study, conducted in } \\
\text { Jawahar Lal Nehru Medical College \& associated group of Hospitals, Ajmer, Rajasthan, } \\
\text { India. A total of } 289 \text { HIV-TB co- infected patients attending ART centre, from January } \\
2015 \text { to December } 2016 \text { were enrolled in this study. CD4 count was done by BD FACS }\end{array}$ \\
\hline Article Info & $\begin{array}{l}\text { count. Statistical analysis was performed with the SPSS. A total of } 289 \text { HIV/AIDS sero- } \\
\text { positive cases on ART having co-infection of TB were included in the study. In our study }\end{array}$ \\
\hline $\begin{array}{l}\text { Accepted: } \\
\text { 04 April } 2017 \\
\text { Available Online: } \\
10 \text { May } 2017\end{array}$ & $\begin{array}{l}\text { EPTB patients } 160(55.36 \%) \text { were higher in number as compared to PTB patients } 106 \\
(44.64 \%) \text {. In majority of cases CD4 count was }<200 \text { cells/ } \mu 1 \text { which were } 171 \text { ( } 59.17) \text {. A } \\
\text { significant correlation was observed with age \& CD4 count. Extra-pulmonary \& sputum } \\
\text { negative pulmonary HIV-TB patients outnumbered the sputum positive HIV-TB co- }\end{array}$ \\
\hline
\end{tabular}

\section{Introduction}

AIDS/HIV has become a worldwide epidemic, affecting different populations and geographic areas and has become the most important public health problem (Geo et al., 2013). An estimated 36.7 million people were infected with HIV, globally, in 2015, out of which 2.1 million were new infections. People living with HIV accounted for 1.2 million $(11 \%)$ of all new TB cases worldwide. India has been reported to be in the $0-4.9 \%$ zone of HIV prevalence in new TB cases. Globally in $2015,55 \%$ of notified TB patients (3.4 million) had a documented HIV test result, an 18-fold increase in testing coverage since 2004 (Global Tuberculosis Report,
2015). According to sentinel surveillance held in 2014-2015 in India, HIV prevalence was $0.26 \%$. Adult HIV prevalence for males was $0.30 \%$ and that of females was $0.22 \%$. The most common age group affected was 15-49 years (National AIDS Control Organisation, 2015)

HIV mainly affects the CD4 cell count, as the infection progresses, the CD4cell count declines. These cells play a major role in body defense against various opportunistic infections, of which the most common is Tuberculosis (TB) (Sameer et al., 2011) Worldwide, in 2015, approximately 1.2 
million people were HIV-TB co infected \& 0.4 million people died with HIV-TB coinfection (Global Tuberculosis Report, 2015). Approximately $60-80 \%$ of HIV- TB coinfected patients have pulmonary Tuberculosis (PTB), and 30-40\% have extra pulmonary TB (EPTB). As the infection progresses there is advanced immunesuppression in HIV-infected persons \& incidence of EPTB rises (Fauci et al., 2015).

HIV-TB co-infection is one of the most health challenging issues worldwide, especially in developing countries like India. HIV- TB coinfection is associated with special diagnostic and therapeutic challenges and constitutes an immense burden on healthcare systems. Globally, HIV is threatening the control of TB. Treatment of co-infection with HIV and TB requires commitment and a focused approach. Appropriate use of antiretroviral drugs to treat HIV infection and ensuring high levels of coverage and compliance is required to prevent TB by preserving immunity.

Against this background, the present study was aimed at evaluation of CD4 cell count and its associating factors in HIV-TB (Pulmonary and extra-pulmonary) co infection to estimate their immune status.

\section{Materials and Methods}

This was a hospital based observational, descriptive \& retrospective type of study conducted on a total of 289 HIV-TB coinfected patients in ART centre of JLN Medical College \& associated group of Hospitals, Ajmer. The two year data was collected from January 2015 to December 2016 of the HIV-TB co-infected patients. The patients on ART were included in the study. Clinical profile \& data of other investigations like cytology, fine needle aspiration and biopsy, acid fast bacilli staining for sputum and other body fluids, culture, cartridge based nucleic acid amplification test, $X$ ray, computed tomography scan, renal function test and liver function test was also retrieved. HIV infection was determined by detection of anti-HIV antibodies by dot immunoassay, immuno-chromatography and immunofilteration (National AIDS Control Organisaiton, 2015). The data of CD4 cell count was taken from CD4 laboratory in ART centre JLN Medical College\& Hospital, Ajmer and was done by BD FACS count (Becton Dickinson Immunocytometery System, San Jose, CA, USA).

\section{Statistical Analysis}

Statistical analysis was performed with the SPSS, Trial version 23 for Windows statistical software package (SPSS inc., Chicago, il, USA) and Primer. The Categorical data were presented as numbers (percent) and were compared among groups using Chi square test. The quantitative data were presented as mean and standard deviation and were compared using by students t-test and ANOVA Test and post Hoc Test Turkey Test applying to find out the most significant groups among all the groups. $\mathrm{P}$ value $<0.05$ was considered statistically significant.

\section{Results and Discussion}

The total study population was 289 cases in two years of duration. In year $2014-15,144$ (49.83\%) and in Year 2015 -16, 145 (50.17 $\%)$ cases attended the hospital. The most common age group of HIV TB co-infection was $>40$ year $(35.64 \%)$ followed by $30-39$ Years 94(32.53\%). Males outnumbered the females $(77.16 \%$ vs $22.84 \%)$. According to CD4 cell Count, 171(59.17\%) cases were in range of less than and equal to 200 cells/ $\square$ lof CD4 count. Only $27(9.34 \%)$ cases, were $\geq 500$ cells/ $\square$ 1CD4 cell Count. (Table no 1).In our study maximum patients had EPTB which were $160(55.36 \%)$ which was followed by 
SP-TB $106 \quad(36.68 \%) \quad$ (Figure no.1) Association of Age and CD4 cell count with HIV-TB co- infection status was statistically significant (Table no 2).

In our study CD4 cell count was significantly less than 200 cells/ $\mu$ l in older age groups as compared to younger age group in which the CD4 cell count was greater than 500 cells $/ \mu 1$. No significant association with gender was observed $(\mathrm{P}=0.076 \mathrm{NS})$. There was no significant association was observed with CD4 cell count with type of TB infection (Table no 2).

In our result we observed a higher number of patients whose had CD4 cell count $<200$ cells $/ \mu 1$ were Extra-pulmonary TB 98 $(61.25 \%)$ as compared to the Pulmonary TB cases 73 (56.58\%). The Mean CD4 cell count in Sputum negative cases was 252.79 \pm 248.99 followed by EPTB \& Sputum positive cases which was 203.38 $188.132 \quad \&$ $175.30 \pm 154.452 .73$ (56.58\%). There was no significant association observed between CD4 cell count and type of TB infection $(\mathrm{P}=0.102 \mathrm{NS})$.

The harmful association between the HIV and tuberculosis epidemics has added dramatically to the suffering and death caused by each disease alone. HIV/AIDS affects mainly the CD4 cell count, as there is decrease in the cell count the chances of opportunistic infection increases. The most common opportunistic infection in AIDS is TB. The HIV-TB co-infection is the emerging threat and most health challenging issues globally.

This study was done on 289 HIV-TB coinfected patients. The most common age group of HIV TB co-infection was $>40$ year $103(35.64 \%)$. Our finding were similar to Siddeswari et al., (2016) in which there were $37.50 \%$ cases, whereas Mihir Bhattacharya et al., (2011) reported slightly higher number of cases in which there were $45 \%$ cases affected in the same age group. This may be due to the fact, that, as the age progresses the immunity decreases (Mihir et al., 2011; Siddeswari et al., 2016). In this study males were affected more than females which was 223(77.16\%). Ketki Jangid et al., (2015) \& Amara Ezeamama et al., (2015) also reported males to be in higher number which were $81.25 \%$ \& $57 \%$ respectively. This may be because of the reason that the male has to migrate for occupation and stay away from spouse for a longer period.

Table.1 Demographic profile of the study population

\begin{tabular}{|c|c|}
\hline Age Group(years) & Number (\%) \\
\hline$<20$ & $36(12.46)$ \\
\hline $20-29$ & $56(19.38)$ \\
\hline $30-39$ & $94(32.53)$ \\
\hline$>40$ & $103(35.64)$ \\
\hline Sex & Number $(\%)$ \\
\hline Female & $66(22.84)$ \\
\hline Male & $223(77.16)$ \\
\hline CD4 cell count (cells/ $\boldsymbol{\mu l})$ & Number $(\boldsymbol{\%})$ \\
\hline$\leq 200$ & $171(59.17)$ \\
\hline $201-350$ & $62(21.45)$ \\
\hline $351-500$ & $29(10.03)$ \\
\hline$\geq 500$ & $27(9.34)$ \\
\hline
\end{tabular}


Table.2 Associating Factors of CD4 cell count(cells/ $\mu 1)$

\begin{tabular}{|c|c|c|c|c|c|c|c|c|c|c|}
\hline & \multicolumn{2}{|c|}{ CD4 $\leq 200$} & \multicolumn{2}{|c|}{ 201-350 } & \multicolumn{2}{|c|}{$351-500$} & \multicolumn{2}{|c|}{$\geq 500$} & Total & $\begin{array}{l}\text { P Value } \\
\text { LS }\end{array}$ \\
\hline $\begin{array}{l}\text { Age } \\
\text { Groups(Years) }\end{array}$ & \multicolumn{2}{|c|}{$N=171$} & \multicolumn{2}{|c|}{$N=62$} & \multicolumn{2}{|c|}{$\mathrm{N}=\mathbf{2 9}$} & \multicolumn{2}{|c|}{$\mathrm{N}=\mathbf{2 7}$} & 289 & \\
\hline$<20$ & 11 & 30.56 & 11 & 30.56 & 5 & 13.89 & 9 & 25.00 & 36 & \\
\hline $20-29$ & 31 & 55.36 & 10 & 17.86 & 9 & 16.07 & 6 & 16.67 & 56 & \\
\hline $30-39$ & 55 & 58.51 & 21 & 22.34 & 9 & 9.57 & 9 & 25.00 & 94 & \\
\hline$>40$ & 74 & 71.84 & 20 & 19.42 & 6 & 5.83 & 3 & 8.33 & 103 & $<0.001 \mathrm{~S}$ \\
\hline \multicolumn{11}{|l|}{ Sex } \\
\hline $\mathrm{F}$ & 33 & 50.00 & 16 & 24.24 & 12 & 18.18 & 5 & 13.89 & 66 & \\
\hline $\mathrm{M}$ & 138 & 61.88 & 46 & 20.63 & 17 & 7.62 & 22 & 61.11 & 223 & $0.076 \mathrm{NS}$ \\
\hline \multicolumn{11}{|l|}{ TB status } \\
\hline Sputum+ & 18 & 78.26 & 2 & 8.70 & 2 & 8.70 & 1 & 2.78 & 23 & $0.33 \mathrm{NS}$ \\
\hline Sputum- & 55 & 51.89 & 28 & 26.42 & 11 & 10.38 & 12 & 33.33 & 106 & $0.33 \mathrm{NS}$ \\
\hline $\begin{array}{l}\text { Extra- } \\
\text { pulmonary }\end{array}$ & 98 & 61.25 & 32 & 20.00 & 16 & 10.00 & 14 & 38.89 & 160 & $1.0 \mathrm{NS}$ \\
\hline
\end{tabular}

Fig.1 Distribution of types of tuberculosis

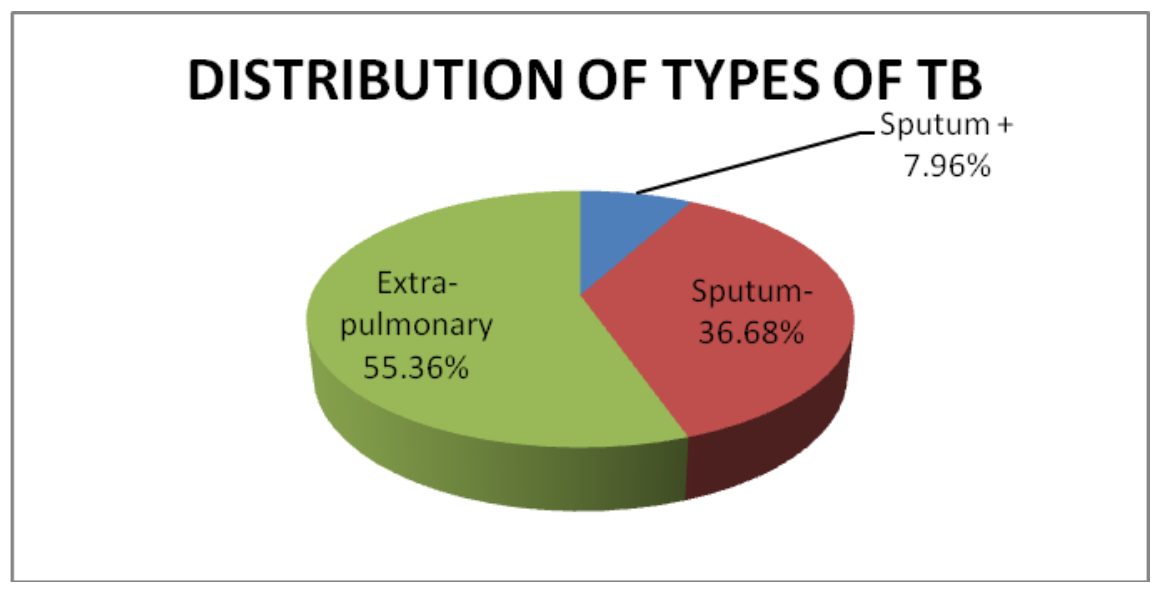

In our study, $160(55.36 \%)$ cases were EPTB followed by 129(44.64\%) of PTB. Our study was comparable with Kavya et al., (2014) in which it was $65 \% \& 35 \%$ respectively. Out of the total PTB cases in our study Sputum-(SP) $\mathrm{TB}$ and Sputum + $(\mathrm{SP}+) \mathrm{TB}$ cases were 106 $(36.68 \%) \& 23(7.96 \%)$ cases, respectively, Leandro Cruz Campos et al., (2014) also had the similar findings which was $41.10 \%$ $\& 36.20 \%$,respectively. Maximum cases i.e
171(59.17\%) had CD4 cell Count of less than and equal to 200 cells/ $\square$ lof CD4 count. Our results correlated with Yasmin et al., (2016) and Siddeswari et al., (2016), in which there were $60.38 \% \& 60 \%$ cases respectively, as there is decrease in CD4 cell count there is increase in opportunistic infections. In our study, age group had a significant association. CD4 cell count of $\leq 200$ cells/ $\square 1$ was significantly more in older age groups 
$74(71.84 \%)$ as compared to younger age group, which was also echoed in study done by Ketki Jangid et al., (2015) 63\%. This is in accordance with the fact that the CD4 cell count decreases with the advancing age.

A higher number patient with Extrapulmonary TB $98(61.25 \%)$ was observed to have CD4 cell count $\leq 200$ cells/ $\mu$ as compared to the Pulmonary TB cases 73(56.58\%). Kavya et al., (2014) reported $58.46 \%$ EPTB and $41.64 \%$ of PTB in the range CD4 cell count $\leq 200$ cells/ $\mu 1$ which was comparable to our results. The direct correlation of all kind of tuberculosis and CD4 cell count depletion was observed. It was also observed that as the age advances the immunity tapers down. Also, the co infection was seen more in male patients, so it is suggested increase monitoring and nutritional support as adjunct therapy should also be considered. Extra-pulmonary and sputum negative pulmonary HIV-TB patients outnumbered the sputum positive HIV-TB patients, which concludes that a newer \& better diagnostic test is required.

\section{Acknowledgement}

A special thanks, to the Project Director and Care Support \& Treatment Division, Rajasthan State AIDS Control Society for providing invaluable co-ordination and support.

\section{References}

Amara, E., Ezeamama, Ezekiel Mupere, James Oloya, Leonardo Martinez, Robert Kakaire, Xiaoping Yin, Juliet N. Sekandi, Christopher, C., Whalen. 2015. Age, sex, and nutritional status modify the CD4+ T-cell recovery rate in HIVtuberculosis co-infected patients on combination antiretroviral therapy. Int. J. Infec. Dis., 3: 73-79.
Chakradhar Rao, G., G.K. Rajeswari, N. Kalyani, J. Siva Kalyani, M.V. Shekar Reddy, K. Vasudha. 2015. Study of clinical, microbiological and radiological correlation of tb: hiv coinfection jemds, 4(6): 905-913.

Fauci, S.A., Lane, C.H. 2015. Human Immunodeficiency Virus Disease: AIDS and related disorders. In: Kasper LD, Braunwald E, Fauci SA, Hauser SL, Longo DL, Jameson LJ, editors. Harrison's Principles of Internal Medicine. 17th ed. New York: McGraw-Hill Medical Publishing Division, Pp. 1249-85.

Geo, F., Brooks, Karen, C., Carroll, Janet, S., Butel, Stephen, A., Morse, Timothy, A., Mietzner, Jawetz. 2013. Melnick \& Adelber's medical microbiology, $26^{\text {th }}$ edition, New York McGraw-Hill Lange, 653-67.

Global Tuberculosis Report. 2015. 20 th edition, Executive summary.

Kavya, S., Anuradha, K., Venkatesha, D. 2014. CD4 count evaluation in HIV-TB co infection before and after antitubercular treatment. Int. J. Res. Med. Sci., 2(3):1031-1034.

Ketki Jangid, Shalini Malhotra, Shiwangi Sharma, Charoo. 2015. CD4 cell counts recovery in HIV/TB co-infected patients in a tertiary care hospital Hans Sch. Acad. J. Biosci., 3(6): 518-521.

Leandro Cruz Campos Marcos Vinícius Vieira Rocha, Denise Maria Cunha Willers and Denise Rossato Silva. 2016. Characteristics of Patients with SmearNegative Pulmonary Tuberculosis (TB) in a Region with High TB and HIV Prevalence, PLOS ONE, DOI:10.1371/journal.pone 2016.

Mihir, K., Bhattacharya, Trailokya, N., Nair, Mrinmoy Ghosh, Sarojit Jana, Phalguni Dutta. 2011. Pulmonary Tuberculosis among HIV Seropositives Attending a 
Counseling Center in Kolkata, Indian J. Pub. Health, 55(4).

Mitku, A.A., Dessie, Z.G., Muluneh, E.K., Workie, D.L. 2016. Prevalence and associated factors of TB/HIV coinfection among HIV Infected patients in Amhara region, Ethiopia. Afri. Health Sci., 16(2): 588-595.

National AIDS Control Organisaiton. 2015. National Guidelines for HIV Testing.

National AIDS Control Organisation. 201415. HIV Sentinel Surveillance, A Technical Brief.

Sameer Singhal, S.K., Diwan, Abhay, M. Gaidhane, Z. Quazi Syed. 2011. Correlation of Sputum Smear Status with CD4 Count in Cases of Pulmonary
Tuberculosis and HIV Co-Infected Indian J. Tuberc., 58: 108-112.

Siddeswari, R., K.S. Amaravathi, N. Srinivasa Rao, Sanjeev, B. Rewari, Prabhu Kumar. 2016. HIV/AIDS-tuberculosis (pulmonary and extra pulmonary) coinfection: CD4 correlation, Int. J. Res. Med. Sci., 4(4): 1035-103.

UNAIDS. $\quad$ Factsheet 2016. http://www.unaids.org/sites/default/files /media asset/20150901_FactSheet_2016_en.pdf Yasmin, T., K. Nandan. 2016. Correlation of Pulmonary Tuberculosis in HIV Positive Patients and its Association with CD4 Count, Int. J. Life. Sci. Scienti. Res., 2(6): 733-736.

\section{How to cite this article:}

Jyotsna Chandwani, Priyanka Soni, Geeta Parihar and Chandrakant Meena. 2017. Evaluation of CD4 Cell Count and its Associating Factors - In HIV-TB Co-Infection. Int.J.Curr.Microbiol.App.Sci. 6(5): 747-752. doi: https://doi.org/10.20546/ijcmas.2017.605.084 